\title{
4. PASSION IN THE WORK OF JOHANN SEBASTIAN BACH
}

\author{
Karol Medňanský17
}

\begin{abstract}
Passions are exceptionally important in the works of Johann Sebastian Bach. His passion compositions are based particularly on Luther's reformation, chiefly on developmental tendency which is based on the works of Johann Walter, Hans Leo Hassler and Michael Praetorius. The most significant forerunner of J. S. Bach was Heinrich Schütz. J. $S$. Bach's textual aspect is aimed at the model of passion oratorio the main representative of which was a librettist Heinrich Brockes who worked in Hamburg. The interesting fact is that before the arrival of $J$. S. Bach, in 1723, there was no long tradition of passions in Leipzig. They were performed there in 1721 for the first time. J. S. Bach is demonstrably the author of the two passions: St Matthew Passion BWV 244 and St John Passion BWV 245. The authorship of Johann Sebastian Bach in St. Lukas Passion BWV 246 is strongly called into question and from St Mark Passion BWV 24 only the text was preserved.
\end{abstract}

Key words: passion, reformation, passion oratorio, heritage, tradition

\section{Introduction}

Passions are of an extremely important significance in composer's heritage by Johann Sebastian Bach (1685 - 1750). Their importance lies not only in the number of songs, but in their exceptional artistic quality which appeals to the contemporary audience. Their importance lies in the deep philosophical message that the author passes to his audience by means of his music and that is perceived by a wide audience, from the religious and secular minded people. The deep Christian faith of the author is reflected in all the attributes of Bach's composer's poetics which is based on the principles of the period in which he lived, the principles that he remained faithful throughout his active composer's work. His passion represent the synthesis of the development of this music genre and Bach reached in it his peak, which has not been beaten by any of his contemporaries nor followers. His passion work is the culmination not only of the music development of passion, but it is also the culmination of the spiritual world that was shaped from the era of Luther reformation in the protestant world culture. He closed the line of ideas and thoughts declared by the great German reformer who in a significant way influenced the development of the European socio-cultural history and of European music.

\section{The Development of Passion}

At the era of Johann Sebastian Bach the passions experienced their peak period in the formation of Protestant church music. In Western European music culture is the history of passion connected with the history of sacred music. Their developmental line can be followed since the story of Jesus Christ, from his passion and death, his story was set to music, to Gregorian one voice chant, and then to more voice motet style, or to the combination of both styles responsorial passion. After the division of West European Church to two confessions - Roman Catholic and Protestant - the development of passion has

\footnotetext{
${ }^{17}$ Associate Professor, PhD., "Prešov University” from Prešov, Slovak Republic, karol.mednansky@unipo.sk
} 
also been oriented in two directions ${ }^{18}$. The development of Protestant passion ${ }^{19}$ was in the beginning closely tied to the liturgy (Braun, 1997, p. 1469). In 1526 essential for the development of passion was the release of the principle of German Mass by Martin Luther $(1483-1546)^{20}$ with the help of his advisor Johann Walter $(1496-1570)$ in the field of music. Johann Walter with his two passions, St. Matthew Passion and St. John Passion from 1545, based on the principle of four-voice choral singing of the Protestant text so called - turbae laid the foundation for further development of Protestant Passion. Two other composers contributed in a significant way to the development of German passion music, Joachim a' Burck (1546 - 1610) and Leonard Lechner (approx. 1553 - 1606) ${ }^{21}$. Burck's Deutsche Passion (German passion) was the first passion published in 1568 before Walter, in the press (Abraham, 2003, p. 228). The other significant inter-stage in the development of Protestant passion is the work of Hans Leo Hassler (1564 - 1612) and Michael Praetorius (1571 - 1621), a significant music theoretician of the first third of $17^{\text {th }}$ century.

Later the development of passion was most markedly influenced by Heinrich Schütz $(1585$ - 1672), the composer in who thanks to his Venetian school came to the crossing of Lutheran hymnody and Venetian structural elements. In addition he is an excellent author of spiritual concerts, such as Geistliche Konzerte ${ }^{22}$, and St. Luke Passion (1653), St. John Passion (1665) and St. Matthew Passion (1666) and he significantly contributed to the development of passion. He followed the principle of both West European confessions that in church there were not allowed musical instruments at the Holy Week. Heinrich Schütz added texts in his passions that were not from Holy Bible: Exordium - in the introduction "Listen about the Pain" - Höret das Leiden - and in the Conclusion - Conclusio - thanksgiving - Gratiarum actio.

There was another personality who together with H. Schütz, a Hamburg schoolmaster - cantor, Thomas Selle $(1599-1663)$, who played an important role in the development of passion. His principle of using intermedium in the text of St. John Passion (1643), is one of the last steps towards the combination of using prosaic text of the evangel, secular songs and modern ecclesiastical poems. This work is significant because Thomas Selle uses musical instruments in it, and some of them characterise particular characters of the play (Abraham, 2003, p. 317): Pilate is accompanied by cornets and trombones, Jesus (bass) and two violins, and evangelist (tenor), by two bassoons ${ }^{23}$. In regard to the fact that

\footnotetext{
${ }^{18}$ In our survey we focus on Protestant confession, mainly on the developmental tendencies of Protestant passion, in respect of the J. S. Bach's adherence to Protestant confession.

${ }^{19}$ Geographically they can be situated in the territory of Middle or Northern Germany.

${ }^{20}$ With the initiation of M. Luther's German Mass closely correspondents the information according to which passions were sung in German language Strasbourg in 1531 in German (Braun, 1997, p. 1469).

${ }^{21}$ Leonard Lechner (approx. 1553 - 1606) is Lasso's student from Munich who converted to Protestant religion.

${ }^{22}$ Their outstanding pioneer was chiefly Johann Hermann Schein (1586 - 1630) - Leipzig Thomaskantor, mainly by his ecclesiastical work Opella nova (1618 and 1626), in which he used as one of the first German composers, basso continuo, and Samuel Scheidt $(1587-1654)$, who in his ecclesiastical concerts approached to the principle of variation cantatas, and thus he in a significant way contributed to the development of this kind.

${ }^{23}$ Braun casts in his St. John Passion for 6 voices and 6 instruments: bassoons, recorders, two cornets and one trombone (Braun, 1997, p. 1477).
} 
during the Holy Week in the churches musical instruments and any instrumental music were not allowed, it is assumed (Abraham, 2003, p. 317), “(...) that Passion was performed in secular buildings or in Hamburg and they had their own law, similarly as in Venice"24. In the development of Protestant passion there was achieved, in the middle of $17^{\text {th }}$ century, the significant turning point. Passion were based on the text from Gospel - that was set to music in its original prose, and ecclesiastical songs (hymns, anthems) were added and performed by choirs or solo singers. To this textural basis recitatives and arias were set to music for solo and choir. In the oratorio, there is an important role of narrator, sang by the gospeller ${ }^{25}$. Due to the common qualities with oratorio the narrator, gospeller, the basis of the text of Gospel and passion are known as oratorio passion by J. S. Bach. The other significant developmental feature of oratorio passions is that they are accompanied by musical instruments. Due to the fact that passions in Catholic confession were not allowed to be accompanied with musical instruments, their development was in this part of Europe reduced and slowed down. Catholic passions continued in their development inspired by Protestant passions in the beginning of $18^{\text {th }}$ century.

The last developmental stage is passion oratorio that started to be performed in Hamburg in the beginning of $18^{\text {th }}$ century, out of sacral buildings. Their main feature was, that the text was not directly citied from the Bible, and the story of Christ's passion, suffering and death comes has its roots in poetry. It is the beginning of Biblical Libretto that used its inner arrangement common with Neapolitan opera. The first libretto of passion oratorio ${ }^{26}$ entitled Der blutige und sterbende Jesus (Bleeding and Dying Jesus) was created by Christian Friedrich Hunold (1681 -1721) and music was composed by Reinhard Keiser (1674 - 1739). It was performed in public in Hamburg in $1704^{27}$. The most significant passion librettist from Hamburg is Heinrich Brockes (1680 1747). Libretto of his passion oratorio Der für die Sünden der Welt ermarterte und sterbende Jesus (For the Sing of the World Jesus was Suffering and Died),

\footnotetext{
${ }^{24}$ We suppose that there in Hamburg ruled their own liberal law that did not allow musicians to perform passions by the accompaniment of musical instruments in churches. The use of musical instruments in passions (in Hamburg) had impact on the practice of Northern Germany. Subsequently, after St. John Passion by Th. Selle was performed in Hamburg, there start to be performed orchestrated passions in the church of St. Michael in the Hanseatic Town of Lüneburg. Its cantor M. Jacobi performed passions in 1652 accompanied by cornet. The archival sources from the church of St. Michael (there in this church J. S. Bach was one of the singers in the years 1700 - 1702) indicate that were performed orchestrated passions: by D. Becker - St. John Passion (1678), J. Gestenbüttel - St. Matthew passion (Braun, 1997, p. 1477).

${ }^{25}$ The character of narrator starts to be excluded in oratorios from that period, and that is quite interesting fact.

${ }^{26}$ It is probable that this kind of passions was created under the influence of the Enlightenment that spreads from France to Germany. Librettos of passions are not influenced by the ideas of the Enlightenment, in Germany of $18^{\text {th }}$ century, we do not know, with the exception of the text to oratorio Jesus on the Mount of Olives (1803) by Ludwig van Beethoven, any oratorio or passion influenced by Enlightenment. However, its impact can be seen in the librettist exempt from quoting biblical texts and the individualisation of librettist as an independent creator and free creator.

${ }^{27}$ In the beginning of $18^{\text {th }}$ century Christian Heinrich Postel (1704) writes the text St. John Passion and in the same year (1704) the text was set to music by young Georg Fr. Händel. However, in the contemporary era the authorship is disputed. It is based partly on the text of the Gospel of St. John and partially constitutes its own libretto. It contains extremely dramatic bass part, once it includes the evangelist, and once Jesus, who is reflected in the aria Es ist Vollbracht $\rightarrow$ and arioso $O$ grosses Werk. These two musical units also influenced the music of Bach when composing aria Es ist Vollbracht $\rightarrow \rightarrow$ from textual and musical aspect (Abraham, 2003, p. 361).
} 
was set to music in 1712 by R. Keiser, and further in 1716 by Georg Fridrich Händel (1685 - 1759) and Georg Philipp Telemann (1681 - 1767), in the year 1718 also Johann Mattheson (1681 - 1764). This significant text was interesting also for J. S. Bach and he adopted eight texts for arias into his St. John Passion BWV 245.

Progressive trends that can be seen in the introduction of passion in Hamburg at the turn of the $17^{\text {th }}$ and $18^{\text {th }}$ centuries, attributed to this city an important position in the development of passion. Oratorios started to be composed also by the Roman Catholic composers and they entered that way an interrupted thread in the development of Catholic Passion.

\section{Passions and their Creation in Leipzig before Johann Sebastian Bach}

The history of introducing passions in Leipzig is relatively short before the arrival of Johann Sebastian Bach to be appointed Thomaskantor (cantor at St. Thomas) and music director in $1723^{28}$. In Leipzig there were passions performed for the first time only a year before the death of Bach's predecessor Johann Kuhnau (1660 - 1722). In 1721 his St. Mark Passion were performed for the first time in the basilica of St. Thomas, while it is assumed that passions were performed subsequently, in 1722 in the same cathedral ${ }^{29}$. Based on a new order that was accepted during Good Friday, after the initial bells, there was performed the song Da Jesus an dem Kreuz stand, which followed by the first part of chorale $O$ Lamm Gottes unschuldig. Before the preaching the worshipers sang Herr Jesu Christ, dich zu uns wend. After the preaching there followed the $2^{\text {nd }}$ part of passion, concluding prayer and final canto. This order of worship was respected during Good Friday in the period of Bach (Küster, 1999, p. 433). Based on aforementioned facts, the performance of Bach's St. John Passion $B W V 245$ on Holy Friday, April $7^{\text {th }}, 1724$ in the temple of St. Nicolas, the passion entered the history of passion in Leipzig.

\section{Passion in the Work by Johann Sebastian Bach}

Johann Sebastian Bach with his passions followed the historical development of this musical kind ${ }^{30}$. In his composer's and personal attitude, there happened one interesting event. Despite the fact that in the beginning of $18^{\text {th }}$ century there was slowly developing the new kind of passion oratorio in Hamburg (this oratorio is of poetic character without the direct use of a text from Gospel), Johann Sebastian Bach follows the older type oratorio passion in his

\footnotetext{
${ }^{28}$ To the city of Hamburg belonged significant position in performing passions. This was not only because they were progressive in performing new kinds of passion oratorios in the beginning of $18^{\text {th }}$ century, but also because of the arrival of G. Ph. Telemann and his position of church music director in 1721. Since 1722, a year after he was in the role of music director, until his death in 1767 , he established regular performance of repeating cycles and alternating texts of the four evangelists: St. Matthew, Mark, Lucas and John Passion. This regularity stimulated and encouraged G. Ph. Telemann to fertility in composing passions and he reached the number of 46 .

${ }^{29}$ Alfred Dürr believes that regarding the illness and death of J. Kuhnau in this year, they were not performed (Dürr, 1999, p. 143).

${ }^{30}$ It is probable that J. S. Bach knew, at least marginally, the work of Luther's colleague Johann Walter (1496 to 1570) and his the most important Early Lutheran Collection for 4-voices Geystliche gesangk Buchlayn (The book of Spiritual Chants), Wittenberg 1524 and Geystliche Lieder for one voice (Spiritual songs) by Valentin Babst, Lipsko 1545 (Abraham. 2003, p. 194). We assume that based on the fact that Bach's library contained complete work of M. Luther and documents that deal about him.
} 
compositions $^{31}$. This kind of passion is based on the text from Gospel and cites it directly. J. S. Bach, however, goes further in his own treatment of passion, and following the text he gains in the work inner integrity and continuity. The text of Gospel is unifying element of the whole work. From musical aspect the work keeps to its sacral cantatas that contain choruses, recitatives, arias, and chorales. Within the frame of this music organising of material, the text chosen acquired a particularly unifying feature. J. S. Bach knew and used also newer trends of the development of passion, passion oratorio ${ }^{32}$, and despite the fact he continues in composing their older textural form ${ }^{33}$. It is obvious that he believes that only the text of Gospel is respectable enough to express the biblical story about the suffering, death and resurrection of Jesus Christ. Passions by Johann Sebastian Bach represent the masterpiece in the field of oratorio passions.

The number of passions composed by this great cantor at St Thomas Cathedral, is even today being investigated by music historians. According to an obituary from 1754 (Schulze, 1972, p. 86), which co-authored the son of J. S. Bach, Carl Philipp Emanuel, his father was the author of five passion compositions ${ }^{34}$. Until now, however, there have been retained only two passion compositions in which we are irrefutably convinced of Bach's authorship: St. Matthew Passion BWV 244 and St. John Passion BWV 245. The authorship of Johann Sebastian Bach is in St. Luke Passion BWV 246 strongly questioned ${ }^{35}$. St. Luke Passion ${ }^{36}$ were made presumably in Weimar $^{37}$ in 1712 and they are strongly influenced, in their composer's concept, by motet. However, from the "piece" St. Mark Passion BWV 247, that was performed in the church of St. Thomas in Lepizig, in 1731, there was preserved only text of this passion ${ }^{38}$, written by the main librettist of Johann Sebastian Bach, Christian Friedrich Henrici $(1700$ - 1764), called Picander.

\section{St. Matthew passion BWV 244}

The first performance of St. Matthew Passion kept to the tradition according to which they their opening was on Holy Friday, April $15^{\text {th }}, 1979$ in the church

\footnotetext{
${ }^{31}$ There is not known the case about the performance of passion oratorio in Leipzig, while Bach worked here (Dürr, 1999, p. 46).

32 From Brockesa, the composer of passion oratorio, were made probably the following texts of arias: numbers19, 31, 32, 58, and 60 (Schmieder, 1976, p. 345).

${ }^{33}$ The two kinds of passions - oratory passion and passion oratorio - they differ from each other essentially only the text that they use.

${ }^{34} \mathrm{~K}$. Küster quite disputes this number when he says that the authors of obituary could be wrong and they could rank between J. S. Bach's passions also the works of other composers that he only "introduced", or they sometimes considered the other version of the same work to be a new work (Küster, 1999, p. 432).

${ }^{35}$ Konrad Küster stated that "(...) the attribution of authorship in St. Luke Passion by Johann Sebastian Bach is a mistake" (Küster, 1999, p. 434). Wolfgang Schmieder in his Thematic-Systematic Catalogue of Works by Johann Sebastian Bacha writes that “(...) the authenticity of the work is strongly challenged” (Schmieder, 1976, p. 355).

${ }^{36}$ It very interesting that this work of Bach inspired Polish composer Krzystof Penderecky (*1933) in the years 1963 - 1966 to write a similar work.

${ }^{37}$ It is evidenced that they were performed for the first time in 1730 in the church of St. Nicholas in Leipzig. There were used the scores by Johann Sebastian Bach and Carl Philipp Emanuel Bach. Their further performance followed in the middle of $40^{\text {th }}$ years of $18^{\text {th }}$ century when “(...) Johann Sebastian Bach rewrote the final chorale of the first part" (Küster, 1999, p. 434).

${ }^{38}$ We suppose that some parts of funereal ode Laß, Fürstin, laß noch einen Strahl BWV 198 are connected to St. Mark Passion and that they were used in this work.
} 
of St. Thomas in Leipzig ${ }^{39}$. Despite the uncertainty of some musicologists about this date as the date of their opening, ${ }^{40}$ this term was set as the term of their premiere. In connection with the formation of St. Matthew Passion it is worth noting the hypothesis of kinship or even sameness stated by Emil Platen about music of the work Funeral music for the prince Leopold of Anhalt-Köthen BWV 244a - Die Trauermusik für Fürst Leopold von Anhalt-Köthen (Platen, 1999, p. 27). This composition that was premiered on March $24^{\text {th }}, 1729$, three weeks before Holy Friday that was the day of performance of St. Matthew Passion, and was preserved in the text form ${ }^{41}$. The author of the text is, similarly as in the case of St. Matthew Passion, Christian Friedrich Henrici-Picander. Emil Platen based on the comparing the number of verses, syllables and schemes of rhyme in 10 from 12 arias of Mourning Music with passion comes to the conclusion that they are "two works closely interrelated by textual structure" - "Hier sind offensichtlich zwei Werke durch ihre Textstruktur eng aufeinander bezogen" (Platen, 1999, p. 29). In other words they are interrelated as parody. We meet with this hypothesis also in both versions According to BA and NBA - in Systematic-Thematic Catalogue of works by Johann Sebastian Bach and Wolfgang Schmieder (Schmieder, 1976, p. 345 and 1990, p. 424).

During the life of Johann Sebastian Bach were his St. Matthew Passion performed several times, with author's musical arrangements while the performance was accommodated to the changes. It is worth noting the performance on Good Friday in 1736 which brought arrangements that concerned:

a) Orchestral changes (arrangements):

- In the number 19, there were transverse flutes replaced by recorders,

- In the number 30, there was bass solo part replaced by alto part,

- In the numbers 56 and 57 there was a lute replaced by viola da gamba.

b) Changes in the details of the structure, which can be seen as major arrangements compared to the older version.

Scientists as well as practising musicians agree that the new adaptation of this work from the year 1736, can be considered an original version of St. Matthew Passion, thanks to its preserved reliable copy of the score (Platen, 1999, p. 33). One of very important decisions that Johann Sebastian Bach made, was to replace the lute in the numbers 56 and 57 (numbers given according to NBA) by viola da gamba. Both musical instruments bear similar symbols that are not joined with music - mainly grandeur and dignity, but also sadness. Viola da gamba was selected by Johann Sebastian probably from two reasons:

1. Acoustic: because viola da gamba as a string musical instrument, is able to sound emotively in a way similar to that of human voice. And that was her main function during all her musical practice.

\footnotetext{
${ }^{39}$ Playing passions during Holy Friday was to Johann Sebastian Bach the musical peak of the year (Steiger, 2002, p. 129).

${ }^{40}$ According to American musicologist and an outstanding performer of old music, Johsua Rifkin, they were originated in earlier period (Platen, 1999, p. 24).

${ }^{41}$ The last owner of autograph was since 1818, Johanna Nikolaus Forkel (Schmieder, 1976, p. 345).
} 
2. Performance: Laurence Dreyfus ${ }^{42}$ believes that Johann Sebastian Bach took into consideration the musical talent of young Karl Friedrich Abel (1723 to 1787), who after the death of his father in 1737 came to Leipzig as a student of Thomasschule, and at the same time he was the member of Leipzig Collegium musicum, which was conducted by famous Leipzig Thomaskantor.

There is another interesting fact, Johann Sebastian Bach knew the father of Carl Friedrich Abel, Christian Ferdinand (1682 to 1737), who was an excellent performer of viola da gamba and cello, from the time of his Köthen years, and their families had a very good relationships. This is evidenced by the fact that Johann Sebastian Bach was the godfather of two children of Christian Ferdinand Abel. Thus we can assume that he was informed of talented son of his friend, and he prepared the part of viola da gamba, based on this knowledge. It is not probable, though, it could happen, that Karl Friedrich Abel was playing the part of viola da gamba in the year 1736, when St. Matthew passion were performed for the second time - and he was only 13 year old. However, Johann Sebastian Bach prepared him with the perspective, that he could be a good musician in the future. The question is, who was playing the part of viola da gamba during the second performance, even if young Karl Friedrich Abel cannot be excluded. It might have roots in our distrust in the ability of talented children in the past.

The next performance of St. Matthew Passion was in the beginning of $40^{\text {th }}$ years of $18^{\text {th }}$ century, where Karl Friedrich Abel was probably playing the viola da gamba. The Matthew Passion are composed on biblical text according to the Gospel of Matthew and they consist of free verses and spiritual song cycles ${ }^{43}$. Free verse to the chorales, recitatives and arias was written by Christian Friedrich Henrici, well known under the artistic nickname Picander. Passions are arranged in the two parts ${ }^{44}$, the first part - musical numbers 1 to 29 , according to Bach's new edition, NBA - was performed before the sermon and the second part -30 to 68 - after the sermon ${ }^{45}$.

From typological aspect St. Matthew Passion is oratorio passion, they follow the text of the Gospel of Matthew. Their structure is related to ecclesiastical cantata ${ }^{46}$, which was at that time influenced by Neapolitan opera, recitatives, arias, duets, choirs or choruses. Johann Sebastian Bach codes his musical testimony into many symbols. According to Ivan Valenta (1995, p. 15) the symbol of the cross that creates overall organisation of individual musical parts in their mutual relationships is the most significant of them (figure 1).

Based on the voices/parts from its premiere in 1736, Johann Sebastian Bach He divided all the apparatus of reproduction into two groups labelled as

\footnotetext{
${ }^{42}$ Dreyfus, Laurence: Nachwort, Johann Sebastian Bach: Drei Sonaten für viola da gamba und cembalo, Edition Peters, Leipzig, p. 56.

${ }^{43}$ Bach's passion texts closely follow the tradition of sermons from $17^{\text {th }}$ century (Axmacher, 2005, p. 9).

${ }^{44}$ These are several music numbers meaningfully arranged in a row.

${ }^{45}$ Internally, the St. Matthew Passion, is divided according to plot and semantic scenes:

$1^{\text {st }}$ part - Introduction (No. 1), Preparation to suffering (No 2 - 17), Actus Hortus (No. 18 - 29).

$2^{\text {nd }}$ part - Introduction (No. 30), Actus Pontifices (No. $31-40$ ), Actus Pilatus (No. $\left.41-54\right)$, Actus Crux (No. 55 - 62), Actus Sepulchrum (No. 65 - 68) (Steiger, 2002, p. 134).

${ }^{46}$ In the beginning of $18^{\text {th }}$ century Neapolitan opera had impact on oratorio. In Bach's case, Neapolitan opera influenced his cantatas and by means of it, also passions and all his vocal and orchestral works.
} 
„Chorus primus” and „Chorus secundus” (Platen, 1999, p.119), while during the cast of each musical number, there is exactly marked which chorus is involved in the performance. The overall orchestration for both "choruses" is as follows: transverse flutes I, II, recorders I, II, oboe I, II, oboe d'amore (oboe of love) I, II, hunting oboe - oboe da caccia I, II, violin I, II, viola, viola da gamba, cello, organ and basso continuo (harpsichord, cello, double bass, and bassoon). Viola da gamba was not the part of the overall orchestral cast, which is based on the position of the viola da gamba and contemporary practice in the orchestration of Baroque Orchestra ${ }^{47}$.

Figure 1. Inner arrangement of musical numbers of St. Matthew Passion BWV 244 by Johann Sebastian Bach forms a cross

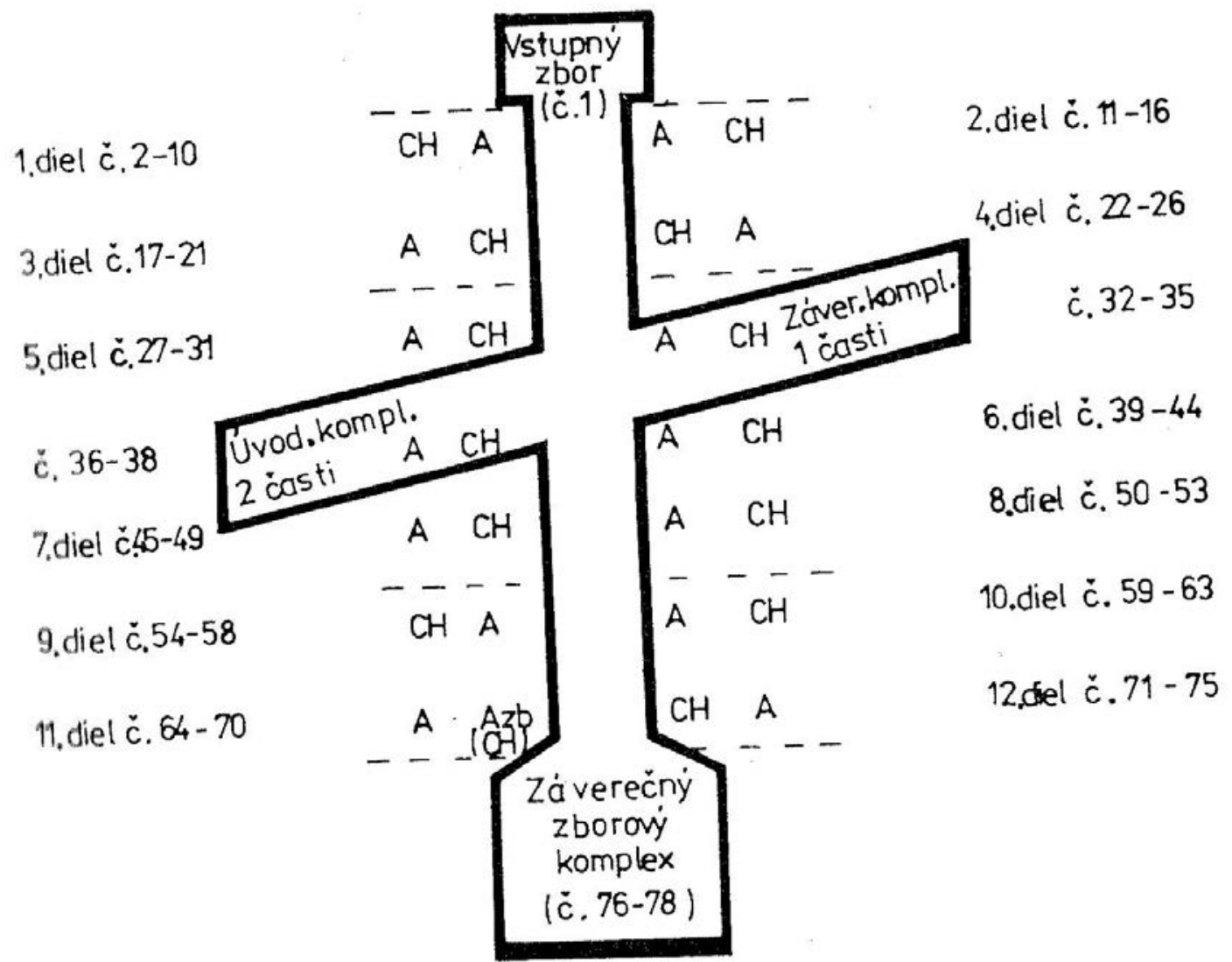

Source: Valenta, I., 1995, p. 15

\section{St. John Passion BWV 245}

Musicians devote a lot of attention to the genesis of St. John Passion BWV 245. There exist several hypotheses that deal with the place and period of their origin $^{48}$. Philipp Spitta's presumption that Johann Sebastian Bach composed St. John Passion while he lived in Köthen and premiered it a bit later, in 1723 in St. Thomas Church, is refuted by Alfred Dürr (Dürr, 1999, p. 14) who considers it

\footnotetext{
${ }^{47}$ There does not exist a reference in historic documents of viola da gamba as the part of Baroque orchestra.

${ }^{48}$ It is conditioned by the fact that there is a lack of exact data and chronology, as well as of the place of origin of majority Bach's compositions.
} 
improbable ${ }^{49}$. The most probable year of completion of St. John Passion it is considered the year 1724, the same year the passion was premiered in Lepizig ${ }^{50}$. By the performance of St. John Passion on Holy Friday, April $7^{\text {th }}, 1724$, Johann Sebastian Bach followed the relatively short tradition of performing passions in Leipzig, which started by the performance of St. Mark Passion by Johann Kuhnau, the predecessor of Johann Sebastian Bach, in the position of Thomaskantor on Holy Friday in 1721. The new Thomaskantor initially wanted to premiere St. John Passion in St. Thomas church, which was his main place of work. At the request of the city council he had to premiere St. John Passion at the St. Nicholas Temple. His responsibilities included also the care of the music production in this temple. That was probably the reason why Johann Sebastian Bach premiered St. John Passion in Leipzig, on the next year March 29 ${ }^{\text {th }}, 1925$, however, in St. Thomas Temple. This event laid foundations of alternating performances of passions in the two temples, St. Thomas and Nicholas (Küster, 1999, p. 433). St. John Passion were performed in Leipzig twice, in 1732 and in 1749. There are different opinions on the date of its third performance. The year 1732 - is presented by Konrad Küster (Küster, 1999, p. 440), while Alfred Dürr presented the third performance of the passion "in 1730" (Dürr, 1999, p. 20). Every performance differed from the previous one in several details, for example in orchestration and in some more fundamental aspects such as in the sequence of musical numbers. If we know about these facts, we have to admit the existence of four versions of St. John Passion. As the basis of contemporary performance of St. John Passions serves the score, which was described by Johann Sebastian Bach approximately in the years 1739 to 1749.

Through the heritage of Carl Philipp Emanuel Bach and the collector George Poelchau $(1773-1838)$, the score was since 1841 the property of the Royal Library in Berlin. It is now under the signature Mus. ms. Bach P 28 at the State Library of the Prussian Cultural Property in Berlin - the former West Berlin (Dürr, 1999, pp. 28-30). The libretto of St. John Passion adheres to the central idea of Biblical text of The Gospel of John according to which Jesus Christ is brought off to the Earth by his Heavenly Father ${ }^{51}$. All the miracles and healings that Jesus Christ did in St. John Passion, are not conditioned by suffering and compassion of people, but they serve to the greater glory of God

\footnotetext{
${ }^{49}$ However, on the other side A. Dürr admits that J. S. Bach could write during his Weimar years his own passions. It is based on the fact that Bach wrote "vocals" of St. Mark Passion (Reinhard Keiser) and he further states that, if he could write "vocals" then he could be motivated to write his own passions (Dürr, 1999, p. 15).

${ }^{50}$ It is certainly interesting that Schmieder in his $1^{\text {st }}$ edition of his Thematic and Systematic Catalogue of works by J. S. Bach" (Tematicko-systematického katalógu diel J. S. Bacha) writes that St. John Passion were written in 1722/1723 in Köthen and were premiered in Leipzig on Holy Friday, in 1723 and their further performance was in Leipzig in 1727 (Schmieder, 1776, p. 345). In the second edition of the same catalogue the author adheres to the latest research results and states that they were premiered on Holy Friday in 1724, and the other time they were performed a year later, in 1725 (Schmieder, 1990, p. 427).

${ }^{51}$ Given that each of the four evangelists brings a message of the suffering, passion and death of Jesus Christ from different perspective, the tradition about the performance of passions during Holy Week, looks very interesting: Palmarum - St. Matthew Passion, Tuesday - St. Mark Passion, Good Friday - St. John Passion. M. Luther's suggestion was to perform the passions on Sunday.
} 
and His Son ${ }^{52}$. According to the key idea of The Gospel of John, the crucifixion is a necessary intermediate halfway house for the return of Jesus Christ to His Holy Father. Libretto of St. John Passion that was set to music, can be classified into three groups:

a) Biblical libretto, was set to music chiefly in recitatives and choruses.

b) Choral libretto.

c) Free verse, poetry sang in arias.

The last group of librettos is very interesting. It carries features of madrigal librettos which were written by Berthold Heinrich Brockes ${ }^{53}$, copied or arranged by the composer. It can be proven that Bach used in his St. John Passion in six numbers the text from Brokes' s librettos: 7, 19, 20, 24, 32, and 34. In the other two numbers, 35 and 39, Bach again adhered to Brokes' text. This time Bach used the material (text) from the other passion. This is true about, for example, aria Es ist vollbracht - opus 30, where Christian Heinrich Postel (1658 - 1705) is the author of the text (Schmieder, 1990, p. 427), and not only author, but also the representative of the transition of a new type of the passion oratorio. It is a very interesting fact that despite the fact that J. S. Bach remained in the typology of older passion oratorio, he used in his passions also the texts of the librettists of the next type of passion oratorio.

From the music aspect, St. John Passion includes 40 musical numbers according to NBA, and according to the older numbering BGA, there is found 68 musical numbers. Music events in passions were divided by the composer into two asymmetric units: the numbers 1 - 14 that were performed before sermons and 15-40 performed after sermons. There are 8 arias, two for a solo: soprano, alt, tenor and basso. The other musical numbers are recitatives, chorales and choruses. The orchestration of Baroque orchestra in St. John Passion constitutes basso continuo: organ, harpsichord, lute, violin, cello, bassoon, and stringed instruments: $1^{\text {st }}$ and $2^{\text {nd }}$ violin, viola d' amore, viola da gamba, $1^{\text {st }}$ and $2^{\text {nd }}$ transverse flute, $1^{\text {st }}$ and $2^{\text {nd }}$ oboe, $1^{\text {st }}$ and $2^{\text {nd }}$ oboe $\mathrm{d}^{\prime}$ amore and oboe d' caccia. This orchestration, however, underwent very interesting evolution, and was changed in each version of passions. We do not know what the versions of the other orchestration (casts) were, because there were not retained the front pages - (Umschlag), where they used to write the orchestration. This is the case, for example, of the $1^{\text {st }}$ version, in which musicologists differ when they talk about the transverse flute. J. S. Bach in majority of his works did not highlight the solo instrument, neither in particular orchestration. Thus the solo instruments have to be deduced from tonality, register and so on ${ }^{54}$.

\footnotetext{
${ }^{52}$ Semantically the best illustration is in $11^{\text {th }}$ chapter, $4^{\text {th }}$ verse: "This sickness is not unto death, but for the glory of God, for the glory of Son of God, who should be glorified by that". (John: $11^{\text {th }}$ chapter, $4^{\text {th }}$ verse).

${ }^{53}$ We would like to remind that Berthold Heinrich Brockes is the main representative of the new kind of passion oratorio. Bach used the texts from Brokes' libretto of passion oratorio Der für die Sünde der Welt gemartete und sterbende Jesus from the year 1712.

${ }^{54}$ This way is disputable the number 9 - Ich folge dir gleichfalls for soprano, obligatory musical instrument and basso continuo. If we suppose that it was designated for solo flute, there is contradiction with Baroque, its unusual tonality B major, and low pitch to $d^{l}$. A. Dürr assumes that it was designated for solo violin, but the
} 


\section{Conclusions}

Both works of passions whose author is demonstrably Johann Sebastian Bach - St. Matthew Passion BWV 244 and St. John Passion BWV 245, played an important role not only in the work of a great Thomaskantor, but also in the development of Baroque music, while they in a significant way affected the further development of music and musical thinking. Music historians and theoreticians agree that in these works, there culminates the overall tendency of the Protestant ecclesiastical church music which is directed to the unity of theology and music. On the other side, commemorative opening of St. Matthew Passion BWV 244 by 20-year-old Felix Mendelssohn-Bartholdy, on Good Friday, March 11, 1829 in Berlin, ${ }^{55}$ marked the beginning of a significant renaissance of Bach's work, who was a well-known composer among musicians of that period. Their reintroduction caught the attention of music loving public to the music of previous eras in the wider European geographical area. That music is nowadays known as "old music". Bach's passion compositions, however, affected and still have an impact on the formation of new generations of composers. For example, on one of the world's most significant composers of the second half of the $20^{\text {th }}$ century, Krzysztof Penderecki $(* 1933)$, who in the years 1963 - 1966 composed his St. Lucas Passion influenced by Bach's St. Lucas Passion. At that time he could not know that J. S. Bach was not their author, and that he had just copied them.

\section{References}

1. Abraham, G. (2003). Stručné dejiny hudby. [A Brief History of Music]. Bratislava: Hudobné centrum

2. Axmacher, E. (2005). „Aus Liebe will mein Heyland sterben” [I Want to die for the Love to the Creator]. Zweite Auflage. Stuttgart: Carus-Verlag

3. Biblia. [Holy Bible]. (2008). Slovenský ekumenický preklad s deuterokánoniclými knihami. Banská Bystrica: Slovenská biblická spoločnost' 4. Braun, W. (1984). Die protestantische Passion. [Protestant Passions] In: Die Musik in Geschichte und Gegenwart: Allgemeine Enzyklopädie der Musik: Zweite, neubearbeitete Ausgabe herausgegeben von Ludwig Finscher: Sachteil. Zv. 7. (pp. 537-540). Kassel; Basel; London; New York; Prag: Bärenreiter

5. Burlas, L. (2006). Formy a druhy hudobného umenia. [Forms and Kinds of Music Art]. $4^{\text {th }}$ ed. Žilina: Žilinská univerzita v Žiline/EDIS-vydavatel'stvo ŽU 6. Dreyfus, L. [s.a.] Nachwort, Johann Sebastian Bach: Drei Sonaten für Viola da gamba und Cembalo [Afterword, Johann Sebastian Bach: Three Sonatas for Viola da Gamba and Harpsichord]. Leipzig: Edition Peters, p. 56

\footnotetext{
paradox is, that in St. John Passion there was not the included violin, and if it was, J. S. Bach would use lower pitch. We think that A. Dürr would prefer lower pitch of a recorder (Dürr, 1999, p. 135). Schmieder in this aria (according to older denomination, No. 13) uses a flute (Schmieder, 1976, p. 347).

${ }^{55}$ Before it was performed, there was a large advertising campaign in the Berlin press where we read ,, The largest and most sacred work of the greatest poet of tones" - Das grösste und heiligste Werk des grössten Tondichters (Platen, 1999, p. 216).
} 
7. Dürr, A. (1999). Johann Sebastian Bach Die Johannes-Passion [Johann Sebastian Bach St. John Passion]. $3^{\text {rd }}$ edition. Kassel; Basel; London; New York; Prag: Bärenreiter

8. Küster, K. (1999). Passionen und Oratorien [Passions and Oratorios]. In: Küster, K. Bach Handbuch (pp. 431-484). Kassel; Basel; London; New York; Prag: Bärenreiter-Verlag; Stuttgart; Weimar: J. B. Metzler

9. Medňanský, K. (2007). PASSIONES BACHIANAE Cesta $k$ vrcholu violy da gamba [BACH'S PASSIONS - the Journey to the Culmination of Viola da Gamba]. Prešov. Prešovská univerzita v Prešove 10. Platen, E. (1999). Johann Sebastian Bach Die Matthäus-Passion [Johann Sebastian Bach St. Matthew Passion]. $3^{\text {rd }}$ supplemented and revised edition. Kassel: Bärenreiter

11. Schmieder, W. (1976). Thematisch-systematisches Verzeichnis der musikalischen Werke von Johann Sebastian Bach Bach-Werke-Verzeichnis $(B W V)$ herausgegeben von Wolfgang Schmieder [Thematic and Systematic Catalogue of Works by Johann Sebastian Bach, Bach - Work - Catalogue (BWV) issued by Wolfgang Schmieder]. Leipzig: VEB Breitkopf \& Härtel Musikverlag

12. Schmieder, W. (1990). Thematisch-systematisches Verzeichnis der musikalischen Werke von Johann Sebastian Bach Bach-Werke-Verzeichnis $(B W V)$ herausgegeben von Wolfgang Schmieder [Thematic and Systematic Catalogue of Works by Johann Sebastian Bach, Bach - Work - Catalogue (BWV) issued by Wolfgang Schmieder]. 2. überarbeitete und erweiterte Ausgabe (p. 427). Wiesbaden: Breitkopf \& Härtel

13. Schulze, H.-J. (1972). Dokumente zum Nachwirken Johann Sebastian Bachs $1750-1800$ [Documents to the Sequential Work of Johann Sebastian Bach 1750 to 1800]. Kassel; Base; Tours; London: Bärenreiter; Leipzig: Deutscher Verlag für Musik

14. Steiger, R. (2002). Gnadengegenwart. Johann Sebastian Bach im Kontext lutherischer Orthodoxie und Frömmigkeit [Johann Sebastian Bach within the Context of Lutheran Orthodoxy and Piety]. Stuttgart-Bad Connstatt: Friedrich Frommann Verlag Günther Holzboorg

15. Valenta, I. (1995). Symbol kríža v Matúšových pašiách J. S. Bacha [Symbol of „Cross" in St. Matthew Passion by J. S. Bach]. Slovenská hudba, roč. XXI, no 1, p. 13-16 